\title{
PEMBERDAYAAN MASYARAKAT MENGOLAH DAUN KELOR MENJADI MINUMAN KESEHATAN DI DESA DAWUNG KEC. PALANG TUBAN
}

\author{
Dyah Pitaloka $^{1 *}$; Tiara Putri Ryandini ${ }^{2}$ \\ 1,2Program Studi Ners Stikes Nahdlatul Ulama Tuban \\ Korespondensi: dyahpitaloka385@gmail.com
}

\begin{abstract}
ABSTRAK
Latar belakang: Teh merupakan minuman yang sangat umum dalam kehidupan seharihari. Produk teh tidak hanya dihasilkan dari daun teh saja tetapi masih banyak tanaman yang dapat digunakan salah satunya adalah tanaman Moringa oleifera lamk atau yang kita kenal dengan Kelor. Tanaman kelor banyak ditanam di daerah Desa Dawung Kec. Palang Kab. Tuban sebagian besar masyarakat memanfaatkan pohon kelor hanya sebagai pagar dipekarangan rumah, masih banyak warga yang belum mengetahui manfaat dari tanaman tersebut. Secara umum dipahami bahwa daun kelor sangat baik untuk tubuh dan membawa banyak manfaat bagi kesehatan kita. Metode: Dengan pelatihan, pendampingan dan evaluasi yang dilakukan selama program pengabdian masyarakat sampai para mitra mampu mengembangkan bisnis dengan baik. Kegiatan ini bertujuan mengembangkan kewirausahaan setiap rumah tangga untuk mendukung pengembangan ekonomi kreatif dan pendapatan keuangan. Hasil :dari kegiatan ini yaitu 1) meningkatkan pendapatan setiap kepala rumah tangga dalam upaya mendukung kegiatan pengembangan masyarakat, terdapat peningkatan pendapatan keuangan meskipun belum dalam sekala besar ; 2) komunitas wirausaha memiliki kemampuan perencanaan bisnis; 3) meningkatkan kemampuan komunitas wirausaha dalam melakukan operasi bisnis. Hasil yang di dapatkan dari pelatihan tersebut adalah warga selain mendapatkan ilmu dalam mengola daun kelor juga mendapatkan pemasukan tambahan dalam keuangan dari hasil penjualan teh kesehatan. Simpulan: Dari kegiatan inidi bahwa masyarakat akan kreatif dan produktif untuk meningkat pendapatan.
\end{abstract}

\section{Kata kunci : Pemanfaatan, Daun Kelor}

\section{PENDAHULUAN}

Teh merupakan minuman yang sangat umum dalam kehidupan sehari-hari.

Produk teh tidak hanya dihasilkan dari daun teh saja tetapi masih banyak tanaman yang dapat digunakan salah satunya adalah tanaman Moringa oleifera lamk atau yang kita kenal dengan kelor. Tanaman kelor banyak ditanam di daerah Desa Dawung Kec. Palang Kab. Tuban sebagian besar masyarakat memanfaatkan pohon kelor hanya sebagai pagar dipekarangan rumah, masih banyak warga yang belum mengetahui manfaat dari tanaman tersebut. Pohon kelor di indonesia sudah dikenal luas sebagai namanya obat khusnya di daerah pedesaan tetapi belum 
banyak dimanfaatkan secara maksimal dalam kehidupan sehari-hari (Hariana,2008).

Tanaman kelor sarat dengan fitonutrien yang merupakan nutrisi nabati yang diyakini memiliki efek mendukung kesehatan. Kelor telah lama digunakan untuk memerangi penyakit kardiovaskuler, obesitas, kolesterol dan juga merupakan elemen penting dalam membangun dan memperbaiki sel- sel dalam tubuh. Betasitosterol adalah komponen dalam kelor yang dapat membantu mengatasi masalah kolestero (Kurniasih, 2012). Daun kelor juga mengandung Vitamin C lebih banyak dibanding jeruk dan kalsium empat kali lipat kalsium susu (Sutanto, dkk., 2007).

Dari manfaat tersebut maka tim sebagai pengusul melalui program Pengabdian kepada Masyarakat mencoba memberikan pelatihan pemanfaatan daun kelor menjadi minuman kelor celup untuk kesehatan tubuh. Di samping melaksanakan pengabdian, pengusul juga bekerja sama dengan mitra lain, salah satunya bekerja sama dengan UKM daerah Kec. Palang Kab. Tuban. Dalam mendukung keberlangsungan usaha dalam pemanfaatan daun kelor menjadi minuman kelor celup untuk kesehatan perlu adanya dukungan dari sumber daya yang ada, yaitu: Sumber daya manusia, produksi minuman sehat dari daun kelor tidak memerlukan keahlian khusus, sehingga pemberdayaan ibu-ibu rumah tangga dan Sumber daya alam, di wilayah desa di Desa Dawung Kec. Palang.Kab. Tuban sangat memungkinkan untuk diberdayakan.

\section{METODE}

Metode pelaksanaan kegiatan beserta solusi yang digunakan dalam mengatasi masalah.

Pelatihan ini di berikan kepada warga ibu rumah tangga di Desa Dawung, yang diwakili sekitar 20 orang.

\section{Tahap Persiapan}

Pelaksanaan kegiatan ini dimulai dengan tahap persiapan yaitu mempelajari referensi terkait dengan pengumpulan data dengan cara mengadakan survey lapangan. 


\section{Tahap Pelaksanaan}

Kegiatan ini dilaksanakan di Desa Dawung Kec. Palang.Kab. Tuban yang diikuti oleh Tim program pengabdian kepada masyarakat bekerjasama dengan UKM dan dibantu 7 mahasiswa. Diawali dengan langkah Tim mengadakan pendekatan dengan mitra tentang persiapan yang akan dilaksanakan dalam program Pengmas, kemudian pengusul menyusun jadwal pelatihan tentang pengemasan daun kelor menjadi teh kelor celup sehingga memudahkan dalam menyeduan teh kesehatan.

Kegiatan Pengmas ini di mulai pada tanggal 15 Desember 2019, kegiatan diawali dari persiapan yaitu berupa survei lapangan, pada tanggal 20 Desember 2019 yaitu dimulainya kegiatan Penyuluhan tentang manfaat daun kelor, Diskusi tentang materi penyuluhan, pengambilan daun kelor. Diskusi tentang materi penyuluhan, pengambilan daun kelor untuk proses penjemuran selama 3-4 hari tidak boleh terkena sinar matahari secara langsung. Pada tanggal 24 Desember 2019 dilaksanakan pendampingan dalam pengelolaan daun kelor dengan cara di haluskan dan di pak didalam kamtung teh celup serta pengepakan yang menarik agar di terima di pasar.

Dalam pelaksanaan program yang dilakukan, mendapatkan respon yang sangat positif dan antusias sehingga akan membuka wawasan bagi masyarakat dalam memanfaatkan daun kelor yang tadinya sebagai sayur-mayur dan sekarang menjadi minuman sehat dalam bentuk kelor celup. Masyrakat tampak antuas dalam pelaksanaan pembuatan teh, diharapkan masyarakat dapat memanfaatkan dan menciptakan suatu kreasi dan inovasi baru dalam memanfaatkan daun kelor.

\section{Tahap Penyelesaian}

Dalam tahapan ini adalah evaluasi dan penulisan laporan kegiatan pengabdian masyarakat, di mana tahap ini membutuhkan waktu selama empat minggu. Tahap ini merupakan tahap yang terpenting dalam pelaksanaan pengabdian tersebut serta juga akhir dari kegiatan dan selama itu juga masih dilakukan pendampingan pada masyarakat desa. Evaluasi dilakukan dengan meninjau ulang ke lahan melihat 
secara langsung untuk mengetahui apakah kegiatan selama ini tetap dilakukan, apakah tepat berjalan lancar sesuai dengan tujuan, sasaran atau tidak, apakah produk masih diterima di masyarakat, masih berguna untuk kegiatan kedepannya agar pengabdian kepada masyarakat ini terus berjalan dan memberikan manfaat khususnya kepada masyarakat Desa Dawung Kec. Palang.Kab. Tuban.

\section{Responden Pelatihan}

Dalam pelatihan ini di ikuti 20 orang ibu rumah tangga dengan rata-rata berpendidikan terakhir Sekolah Menengah Pertama dan Sekolah Menengah Atas dengan tidak bekerja.

\section{HASIL DAN PEMBAHASAN}

Pada kegiatan ini ada beberapa langkah yang dilakukan dalam kegiatan pengabdian masyrarakat, sebagai kelancaran dan keberhasilan kegiatan. Adapun implementasi dari kegiatan pengmas adalah:

1. Penyuluhan tentang manfaat pentingnya daun kelor, berdasarkan penelitian bahwa daun kelor memiliki berbagai manfaat. Hasil penelitian Fuglie (2001) menyatakan bahwa daun kelor memiliki berbagai kandungan nutrisi yang bermanfaat. Kandungan yang paling diunggulkan pada tanaman ini yaitu protein, vitamin A ( $\beta$-karoten), dan zat besinya yang tinggi sehingga bagus untuk dikonsumsi dan dapat memenuhi kebutuhan gizi terutama pada kelompok rawan (Madukwe, et al., 2013). Tidak hanya itu, daun kelor juga mengandung berbagai macam asam amino di mana hal ini jarang sekali ditemui pada sayuran (Kasolo, 2010). Manfaat lain yang dimiliki daun kelor yaitu mampu meningkatkan status gizi pada anak malnutrisi. Saat ini pemanfaatan daun kelor sebagai produk makanan dan minuman sedang berkembang karena daun kelor mempunyai manfaat yang baik untuk kesehatan. Menurut Simbolan, dkk. (2007) daun kelor bermanfaat untuk mengobati berbagai penyakit diantaranya yaitu demam, radang usus, reumatik, pegal linu, diare, rabun ayam, disentri, diabetes, bronchitis, radang selaput lendir, pencuci perut, meningkatkan air susu ibu (ASI). Dengan memberikan informasi tentang manfaat daun kelor tersebut sehingga masyarakat Desa Dawung Kec. Palang.Kab. Tuban 
dapat memanfaatkan daun kelor yang selama ini dijadikan sayur berkuah sebagai pendamping dalam menu makanan. Penyuluhan dilaksanakan tanggal 20 Desember 2019 yang dimulai pukul 08.30 sampai selesai. Masyarakat desa sangat antusias dalam acara tersebut. Informasi yang di dapat masyarakat membuat mereka akan berfikir untuk berkreasi dan berinovasi tentang bagaimana daun kelor bisa dimanfaatkan dalam inovasi produk yang lain.

2. Pendampingan dalam mengelola daun kelor menjadi minuman teh daun kelor untuk kesehatan tubuh perlu dilakukan agar bisa menghasilkan produktifitas yang baik dan masyarakat bisa mengetahui bagaimana proses pembuatan daun kelor menjadi minuman teh ekstrak daun kelor. Ini dilakukan setelah adanya pengarahan dan kemudian langsung dipraktikkan oleh masyarakat.

3. Pada kegiatan ini pendampingan adalah hal yang paling penting meskipun kegiatan pendampingan masyarakat telah selesai dilaksanakan, karena pengusul akan selalu memantau setiap kegiatan yang dilakukan masyarakat agar supaya produktifitas tetap berjalan dengan lancar. Apalagi banyaknya pohon Kelor yang ditanam oleh masyarakat menjadikan program ini dapat berkelanjutan dan menguntungkan bagi masyarakat.

Teh daun kelor dalam kemasan celup instan ini termasuk inovasi baru dalam mengolah daun kelor yang ada di Desa Dawung Kec. Palang.Kab. Tuban. Hal ini dikarenakan masyarakat pada umumnya hanya terbatas menjadikan sayur, sehingga masyarakat mendapatkan ilmu baru dalam mengolah daun kelor. Berikut adalah tata cara mengolah daun kelor menjadi minuman teh daun kelor ;

1. Daun kelor dijemur atau diangin-anginkan di tempat yang dingin (bukan di bawah terik matahari) selama 3-4 hari.

2. Jika sudah layu (tidak sampai kering) kemudian dihaluskan sampai halus. 
3. Kemudian dimasukkan di kantong kertas tipis kecil kemasan seperti teh celup.

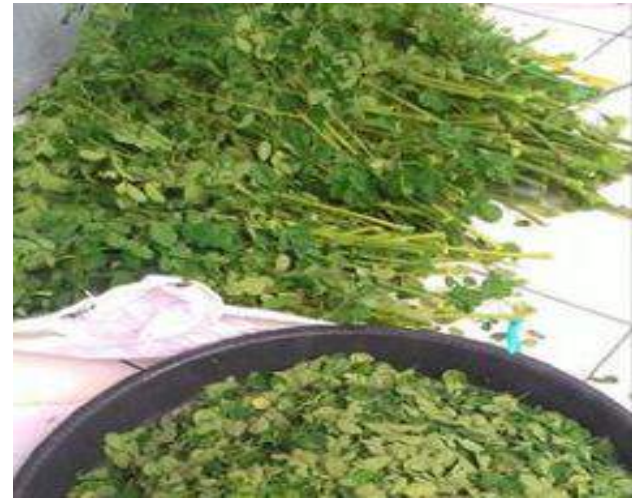

Gambar 1. Penjemuran daun kelor
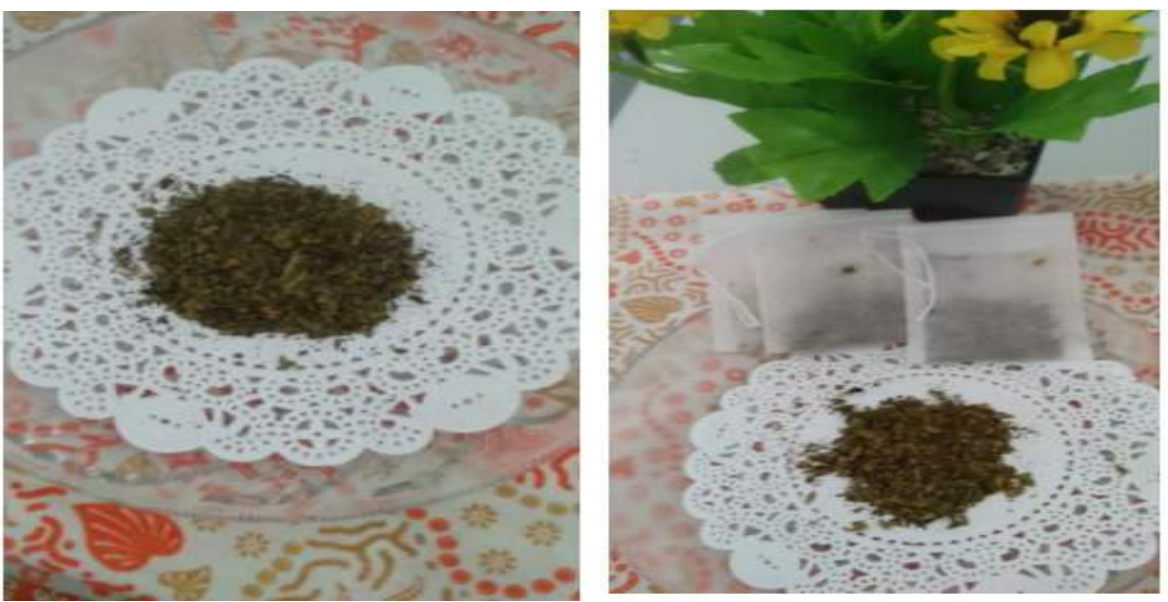

Gambar 3.dan 4 Setelah di haluskan dan setelah di kemas kedalam kantong teh celup

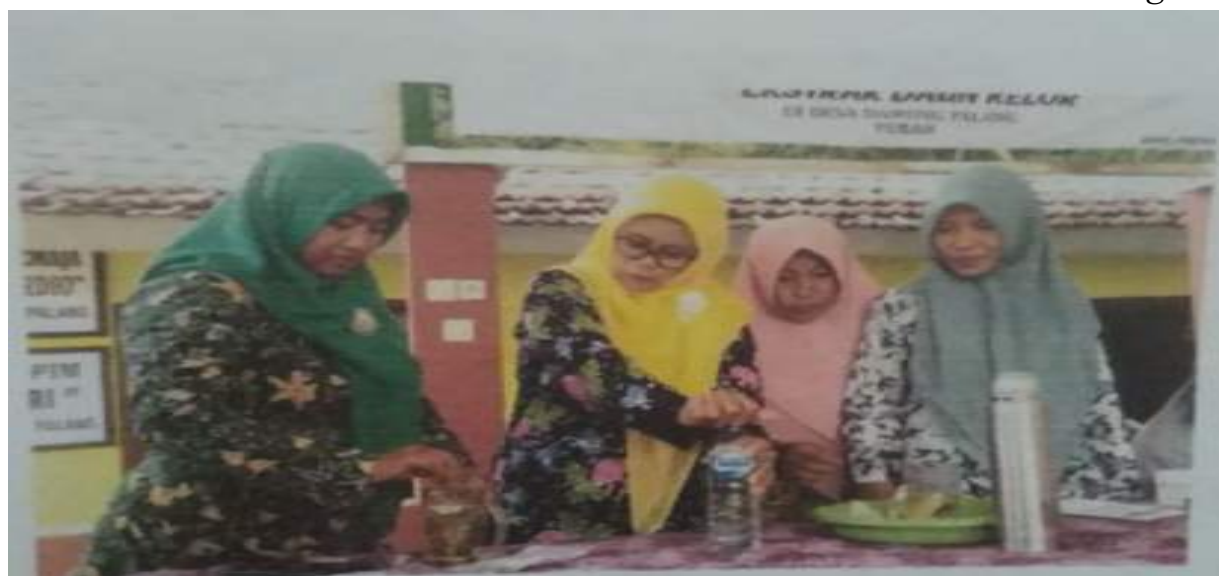

Gambar 5. Praktik penyeduan teh daun kelor instan
Gambar 2. Hasil dari penjemuran

(1)


Program Pengabdian kepada masyarakat di Desa Dawung Kec. Palang.Kab. Tuban, di harapkan dapat memberikan manfaat kepada masyarakat, semula daun kelor hanya sebagai sayur untuk konsumsi harian, dengan adanya pendampingan masyarakat maka dapat memberikan nilai jual terhadap daun kelor yang telah diolah menjadi teh daun kelor instan dan pada akhirnya, dari inovasi teh daun kelor instan tersebut dapat memberikan tambahan ekonomi pada masing-masing keluarga. Selain menjadi pemasukan tambahan pendapatan ekonomi masyarakat dengan mengkonsumsi teh daun kelor tersebut bisa menjadikan tubuh sehat.

\section{SIMPULAN}

Dari pendampingan masyarakat yang dilaksanakan maka dapat disimpulkan sebagai berikut:

1. Pengabdian Kepada Masyarakat akan lebih kreatif dan produktif mengolah sumber daya alam utamanya adalah daun kelor, sehingga perekonomiannya menjadi lebih meningkat.

2. Daun kelor awalnya hanya sebagai sayur, dengan menjadikan minuman teh daun kelor maka akan semakin tinggi nilainya, karena pengemasan dan promosi manfaat bagi kesehatan tubuh.

3. Pendampingan pada masyarakat harus tetap dilakukan agar masyarakat terus berkembang dan mandiri.

Saran yang bisa diberikan sesudah pelaksanaan untuk para pendamping masyarakat, khususnya pendampingan masyarakat Desa Dawung Kec. Palang.Kab. Tuban :

1. Pelakanaan program pengabdian, pelaksana hendaknya melakukan pendampingan yang lebih intensif sehingga masyarakat menerapkan pengetahuan secara mandiri.

2. Masyarakat bisa memanfaatkan daun kelor dengan cara inovasi yang lain tidak terbatas pada teh daun kelor saja.

3. Perlu bekerja sama dengan pihak-pihak lain guna pengadaan barang elektronik berupa mixer (pengaduk) dan lain sebagainya agar proses pengabdian kepada masyarakat berjalan dengan lebih baik dan lancar. 


\section{UCAPAN TERIMAKASIH}

1. Kepada yang terhormat Bpk. Karsilan selaku kepala Desa Dawung Kec. Palang.Kab. Tuban telah diberikannya ijin dan vasilitas pelatihan pada masyarakat desa.

2. Kepada seluruh masyarakat Desa Dawung Kec. Palang.Kab. Tuban dalam pelaksanaan kegiatan pelatihan pemanfaatan teh herbal daun kelor sebagai minuman kesehatan. 


\section{DAFTAR PUSTAKA}

Hariana. (2008). Tumbuhan obat dan khasiatnya. Jakarta: Niaga Swadaya.

Kurniasih. (2012). Khasiat dan Manfaat Daun Kelor untuk penyembuhan berbagai penyakit. Cetakan Pertama, Yogyakarta : Pustaka Baru Press.

Mardiana, L. (2013). Daun Ajaib Tumpas Penyakit, Kanker, Diabetes, Ginjal, Hepatitis, Kolesterol dan Jantumg. Cet.4. Jakarta : Penebar Swadaya.

Sutanto, T., Adfa, D., \& Taringan, N. (2007). "Buah kelor (moringa oleifera lamk.) tanaman ajaib yang dapat digunakan untuk mengurangi kadar ion logam dalam air". Jurnal Gradien, 3(1), 219-221.

Funglie, L.(2001). Combating Malnutrition With Moringa. Development potential for Moringa products, 1(1), 1-4.

Madukwe, E., Ugwuoke, A. \& Ezeugwu, J. (2013). Effectiveness Of Dry Moringa Oleifera Leave Powder In Treatment Of Anemia. Academic Journals, 5(5), 226-228. Diakses dari www. academicjournals.org/

Kasolo, J.N. (2010). Phytochemicals and Uses of Moringa Oleifera Leaves in Ugandan Rural Communities. Academic Journals, 4(9), 753-757. Diakses dari www.academicjournals.org/

Simbolon, J.M., Sitorus, M., \& Nelly, K. (2008). Cegah Malnutrisi dengan Kelor. Yogyakarta: Kanisius. 